\title{
TLR2 e neutrófilos potencializam o estresse, apoptose e descolamento de células endoteliais: implicações para a erosão superficial em síndromes coronarianas
}

\author{
Acadêmico: Haniel Alves Araújo \\ Orientadores: Thibaut Quillord, Peter Libb
}

Introdução: Aproximadamente um terço das síndromes coronarianas agudas resultam da erosão superficial de da íntima, sem sinais de ruptura capa fibrosa, a partir do desnudamento da camada endotelial por mecanismos ainda não elucidados. Este estudo testou a hipótese de que a ativação do Toll-like receptor 2 (TLR2) contribui para a apoptose e desnudamento endotelial e ativação de neutrófilos, contribuindo para a patogênese de erosão superficial.

Métodos e resultados: A partir do nosso banco de artérias com placas ateroscleróticas humanas ( $\mathrm{n}=56)$, as categorizamos com base em características morfológicas associadas à erosão superficial, ou ruptura de placa. Análises morfométricas dos ateromas evidenciaram co-localização de neutrófilos e redes extacelulares de neutrófilos (NETs) junto a aglomerados de células endoteliais apoptóticas em placas com erosão superficial. O número de células apoptóticas endoteliais correlacionase com a acumulação de neutrófilos ( $p<0,001)$, quantidade de NETs $(p<0.01)$, e expressão de TLR2 ( $<<0.05)$ em placas com erosão superficial, mas não em placas com ruptura. TLR2 e neutrófilos também colocalizam-se na superfície de placas humanas com erosão superficial $(\mathrm{p}=0.006)$.

Em experimentos In vitro com células endoteliais humanas, ligantes de TLR2 (incluindo ácido hialurônico, uma macromolécula de matriz abundante em placas com erosão superficial) induziram estresse endotelial, caracterizada pela produção de espécies reativas de oxigênio, estresse do retículo endoplasmático (RE) e apoptose. Co-incubação de neutrófilos com células endoteliais com potencializou estes efeitos na presença de ligantes de TLR-2 e induziu apoptose destas células além de descolamento da matriz.

Conclusão: Nossos estudos in vitro e análises de placas humanas indicam que a estimulação de TLR2 seguido de ativação de neutrófilos e NETs pode tornar placas ateroscleróticas suscetíveis à erosão superficial e complicações trombóticas. Isto decorre da indução de estresse do RE, apoptose, além do favorecimento do descolamento e injúria de células endoteliais que caracterizam a fisiopatologia destas artérias ateroscleróticas. 